\title{
A Study on Difficulties and Solutions in English Speaking Skills of Students at Hufi
}

Citation: Nguyen, Tuyen. (August 23, 2021). A22 STUDY ON DIFFICULTIES AND SOLUTION IN SPEAKING SKILLS OF STU-DENTS AT HUFI. 23 https://osf.io/preprints/socarxiv/e2bn9. 24 LAM NGUYỄN 26

Received: August 17, 2021 Accepted: August 23, 2021 Published: August 23, 2021

Publisher's Note: MDPI stays neutral with regard to jurisdictional 33 claims in published maps and institu 34 tional affiliations.

Copyright: (c) 2021 by the authors. Submitted for possible open access8 publication under the terms and conditions of the Creative Common\$9 Attribution (CC BY) license 40 (https://creativecommons.org/license 41 s/by/4.0/).
1 Ho Chi Minh City University of Food Industry; tuyennguyenpcy@gmail.com

* Correspondence: tuyennguyenpcy@gmail.com; Tel.: 0354029852

\begin{abstract}
Speaking skill is one of the most necessary skill in English to communicate in our daily life. When learning speaking skills, what you aim for is how to communicate naturally and fluently with foreigners. People can have good writing and listening skills if you have a good grasp of vocabulary and grammar but your reflexes are poor. Some common reasons why HUFI students have difficulty speaking English are afraid of communication, lack of training environment, poor vocabulary and grammar. Nowadays, English has been introduced into teaching from primary school level. Students learn grammar and vocabulary, practice reading in books. So you have less chance to practice speaking. This situation goes on continuously and lasts up to university, making your English speaking skills poor. Because they are not sure about speaking skills, most students have difficulties in communicating in English. With the above reasons, the aim of this research is to investigate the difficulties and solutions to improve students' speaking skills of HUFI., help students confidently communicate in English in all situations and in daily life.
\end{abstract}

Keywords: speaking skill, naturally, fluently, afraid of communication, lack of environment, poor vocabulary, grammar

\section{Introduction}

Nowadays, in the trend of globalization, English has become an international language widely used in many parts of the world. With the continuous development of the world, people's demand for learning English is increasing day by day. For the purpose of finding a job or studying abroad, English learners not only want to master the knowledge to take the exam but also want to develop their communication ability. However, they often encounter many difficulties. And there are many influencing factors such as: student motivation, student characteristics, learning materials, teachers' teaching methods, affecting the results of students' English speaking skills. Of the four skills, speaking is especially emphasized. However, students have a lot of difficulty in learning this skill. That is one of the reasons why I wanted to do a research to find out the common difficulties in learning speaking skills and find some suitable solutions to overcome these difficulties. It will help students know more about the difficulties in learning English communication, thereby overcoming mistakes to be more confident in their English ability.

\subsection{AIMS OF THE STUDY}

The study is done with the following aims:

Firstly, the research was conducted with the aim of surveying the status of learning English speaking skills at HUFI to find out the causes and find ways to overcome those difficulties. 
Second most students find it difficult to learn speaking skills, so this study explores the common difficulties that students face when learning English speaking skills at HUFI.

Finally, because of many difficulties, many students have not found the best method of learning and practicing skills in class, so the research will offer some solutions to overcome these difficulties. These studies will be very helpful for students in English speaking lessons. These suggestions are expected to help students speak English fluently, clearly and confidently so that they can improve their communication ability.

1.2. Research questions:

1) What are the difficulties you encounter when speaking English?

2) What is your method of learning English?

3) How to overcome these difficulties?

\subsection{SCOPE OF THE STUDY:}

This study aims to find out the difficulties in learning speaking skills of HUFI students. There are many difficulties that learners may encounter when learning a foreign language. However, due to limitations, the study only focused on the most common difficulties in speaking skills of HUFI students. Then this study will also offer some solutions for students to overcome those difficulties and improve their speaking skills.

\subsection{SIGNIFICANCE OF THE STUDY:}

By understanding students' difficulties in learning English speaking skills and some remedies, it is hoped that the results of the study can be used as a reference to help students learn English speaking skills better. Finally, it is hoped that this study will contribute to the knowledge of HUFI students' difficulties in learning English speaking skills.

\section{Literature Review}

\subsection{Definition of speaking skill?}

Speaking is a very important skill, it helps people in communication to be able to convey their meaning or message to others. so far, there have been a number of definitions of speaking skill by different linguists such as: Tarigan (2008); Departmen Pendidikan Nasional (2004); Wilson (1983); Risnadedi (2001); Freeman (Freeman, 2001); Cameron (2001); Rivers (1981); Brown (1994); Grognet (1997); Brown (1994); Burns \& Joyce, (1997).

Tarigan (2008) defined "Based on Competence Based Curriculum speaking is one of the four basic competences that the students should gain well. It has an important role in communication. Speaking can find in spoken cycle especially in Joint Construction of Text stage".

Department Pendidikan Nasional (2004) stated, "When we speak we produce the text and it should be meaningful. In the nature of communication, we can find the speaker, the listener, the message and the feedback. Speaking could not be separated pronunciation as it encourages learners to learn the English sounds". 
According to Freeman (2001) stated, "Speaking ability more complex and difficult than people assume, and speaking study like study other cases in study of language, naturalize many case to language teachers".

Tarigan (2008) stated, "It means that speaking as the way of communication influences our individual life strongly. So, in this process we can call it is an interaction between two sides. When someone speak to other person, there will be a relationship. The relationship itself is communication".

Wilson (1983) regarded, "Speaking is the development of the relationship between the speaker and the listener. In addition to speaking, determine which logical, psychological, and physical linguistic rules should be applied in a given communication situation. It means that the main goal of speaking is to communicate.".

Richard (2008)stated, "Speaking we tend to be getting something done, exploring ideas, working out some aspects of the world, or simply being together. 'f the students can speak English fluently that can help them to easy communicate and also explore their idea. Speaking English well also helps students to access up to date information in fields including science, technology and health and so on".

Cameron (2001) stated, "There are three important points of speaking skills. First, by productive skill is meant the ability of a person to actively produce the language by coordinating the organs of speech. Second, to express meaning means that the purpose of producing language in verbal communication to deliver ideas so that the speaker can convey meaning to the listener. Third, being able to be directly and empirically observed means that the implementation of speaking can be directly heard or seen in the speaking process by looking at the correctness and effectiveness of the speaker".

Rivers (1981) defined, “Outside the classroom, listening is used twice as often as speaking, which in turn is used twice as much as reading and writing. Inside the classroom, speaking and listening are the most often used skills".

Brown (1994) stated, "They are recognized as critical for functioning in an English language context, both by teachers and by learners. These skills are also logical instructional starting points when learners have low literacy levels (in English or their native language) or limited formal education, or when they come from language backgrounds with a nonRoman script or a predominantly oral tradition".

According to Grognet (1997), "With the drive to incorporate workforce readiness skills into adult ESL instruction, practice time is being devoted to such speaking skills as reporting, negotiating, clarifying, and problem solving ".

Brown (1994) stated, "Speaking is an interactive process of constructing meaning that involves producing and receiving and processing information". 
Burns \& Joyce, (1997) its form and meaning are dependent on the context in which it occurs, including the participants themselves, their collective experiences, the physical environment, and the purposes for speaking".

From the definitions of the experts above, it can be concluded that speaking skill is a language related to communication. Speaking is the skill of using language appropriately to express someone's ideas, opinions or feelings in order to provide or obtain information and knowledge from others.

2.2. Aspects of speaking skills:

There are many different aspects of speaking skills. Based on Brown (2001), there are four suggested speaking skills namely fluency, accuracy, pronunciation and vocabulary.

\subsubsection{Fluency:}

Fluency is defined as the ability to speak fluently and accurately. Fluency is usually defined as expressing language freely without interruption. During the teaching and testing process, if the teacher wants to check the fluency of the students, the teacher will let them freely present without interruption. The purpose of this is to help students speak fluently and understandably. The teacher will not correct immediately, because while editing too much will distract students, and interfere with the flow of conversation.

\subsubsection{Accuracy:}

The second aspect is accuracy. Accuracy is the ability to produce correct sentences using correct grammar and vocabulary in natural magic Brown (2001). It means achieving accuracy by allowing the speaker to focus on grammatical, phonological elements. The aspect of accuracy in the speaking class is established by exposing learners to everyday life including communicative tasks and activities such as talking, role-playing, debating. These types of activities can engage learners in the most natural interactions whenever possible.

\subsubsection{Pronounce}

Furthermore, the third aspect concerns pronunciation. Good pronunciation of language is useful in casual communication, especially in terms of comprehension. Pronunciation is a way for students to make language clearer when they are speaking. That means students can communicate with good pronunciation and intonation even though they have limited vocabulary and grammar. From that statement, it can be concluded that pronunciation is a way for students to make words sound clearly when they speak. Based on the above statement, it can be concluded that pronunciation covers many aspects such as pronunciation, rhythm, intonation and manner of speaking and moreover, gestures, body language and eye contact. 
The last aspect is vocabulary. This is one of the important aspects of learning a foreign language. With a limited vocabulary, people will also have a limited understanding of speaking, reading, listening and writing). And it is impossible to convey very few words without vocabulary nothing can be conveyed. Without sufficient vocabulary, someone cannot communicate effectively with journalism and electronics. Vocabulary is essential to the successful use of a second language because without a rich and varied vocabulary we would not be able to use the structure and function we may have learned to communicate. in an easy to understand manner. It goes without saying that the key to successful communication is the power of vocabulary.

\section{Materials and Methods}

\subsection{The Study Design:}

This study will fully analyze the data collected through student surveys, student interviews about difficulties affecting English speaking skills of HUFI students. The data was collected by 80 professional students at HUFI.

\subsection{Research Instrument:}

For the purpose of conducting survey research with students, surveys were conducted and data was collected. The data will be analyzed in the data analysis section and represented by bar charts and pie charts.

\subsection{Participants}

This study investigates the difficulties and ways to overcome the English speaking skills of students at HUFI. For the purpose of investigating the difficulties of English majors in learning speaking skills at HUFI, we have chosen a survey research method, which is a descriptive study. To collect data for this study, 80 students were invited to participate. The students came from different classes, different faculties and were all randomly selected. In this study, the questionnaire was for students majoring in English. The content of the survey is to help students clearly identify problems about difficulties when learning speaking skills at HUFI.

\section{Results}

After analyzing the research results, it can be seen that students are facing a lot of problems in speaking English including lack of confidence, shyness to communicate, not mastering grammar and vocabulary, lack of training environment. This study has pointed out the factors that make it difficult for students to learn English speaking skills. In addition, this study also focuses on finding out some causes and solutions to overcome this common situation of students. In general, looking at the results, it can be concluded that most students who learn this skill do not use English much in and out of the classroom and do not practice much pronunciation, so their pronunciation is not good. Moreover, the lack of knowledge of grammar and vocabulary is the main reason leading to their shyness in speaking English. And to be able to overcome these obstacles, the research has also provided some solutions to their English speaking problems, the article has suggested that teachers should consider more teaching methods, exercises or activities that can develop students' vocabulary and speaking skills. They may not have noticed the interactive, stimulating activities that can help students master speaking skills. Moreover, the lack of vocabulary is another serious problem that affects students' confidence and fluency in speaking English. People can see that anyone who wants to speak a certain language must 
learn the grammar and master the vocabulary of that language. This suggests that teachers should be more aware of students' difficulties and shyness in speaking English. To help students learn more about linguistic aspects as well as grammar and pronunciation. It is more important that teachers should teach those aspects clearly and easily so that students can absorb the knowledge of those aspects best. Hopefully this method will help in developing students' English speaking ability. So that students can succeed in speaking English well with confidence and fluency.

\subsection{Figures}

This section will show how the results were obtained, explained using percentages and a summary of the findings relative to the research questions.

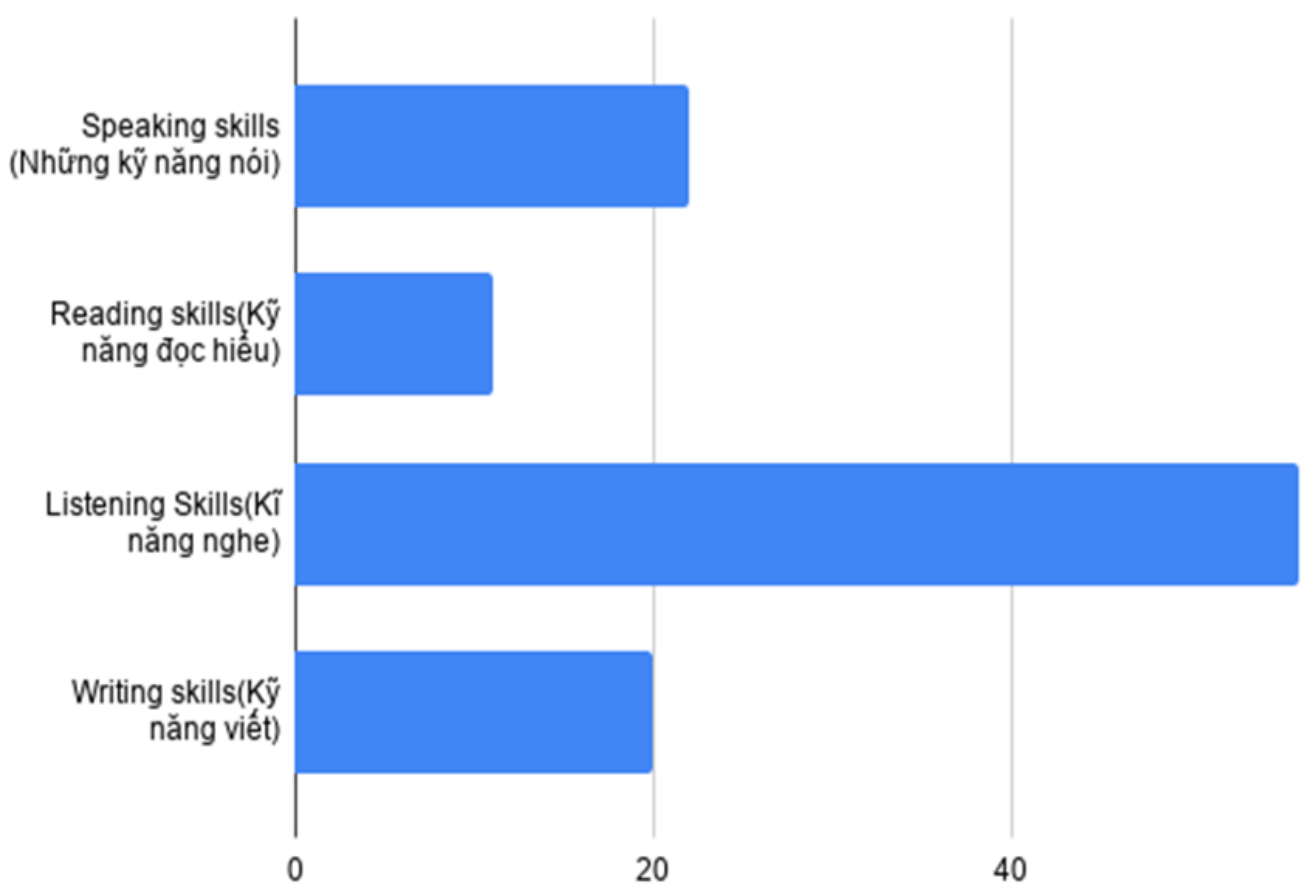

Question 1: What is the most difficult skills in learning foreign language? According to the chart, surveyed students rate the most difficult skill of English, with $54 \%$ of students speaking listening skills accounts for the highest percentage, followed by $21 \%$ speaking skills. Rate $20 \%$ of the difficulty level of writing skills and with $9 \%$ of skills of reading skills. 


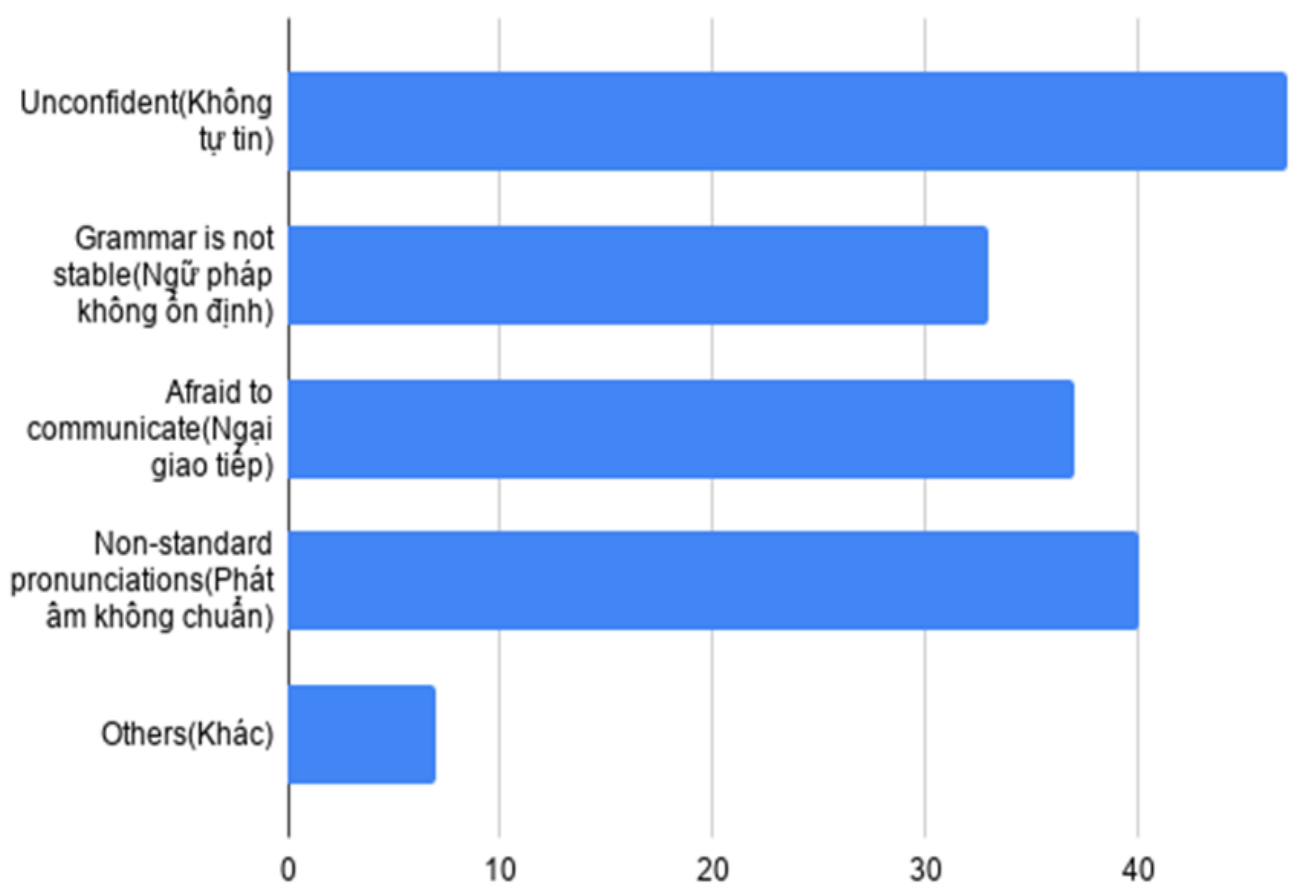

Question 2: What are the difficulties you encounter when speaking English?

When surveyed about the difficulties that students face when speaking English, up to $46 \%$ of students say that they are not confident, $40 \%$ of students think that their pronunciation is not standard and $36 \%$ of students are afraid to communicating with others, $32 \%$ of students said that they have unstable grammar, and $7 \%$ of students said that there are other reasons.

\section{Do you like to communicate in english?}

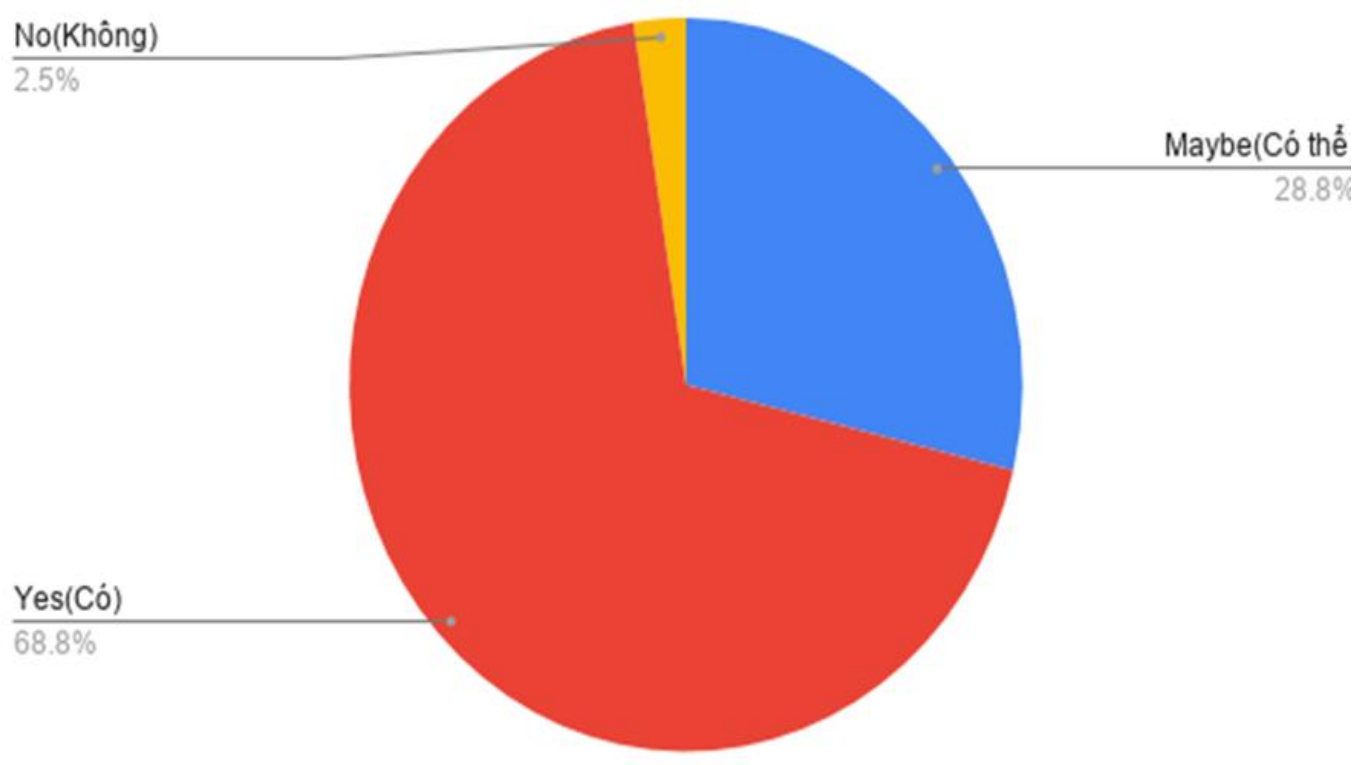

Question 3: Do you like to communicate in English? 
The survey has shown that despite many difficulties in learning speaking skills, $68.8 \%$ of learners still love this skill and $28.8 \%$ of them think that they can like to speak. It can be seen that speaking is a very important skill in learning a foreign language and it is not as difficult as many people think. Only about $2.5 \%$ of students did not like it. For them, learning to speak may not be interesting and engaging, and it can be boring depending on the lesson.

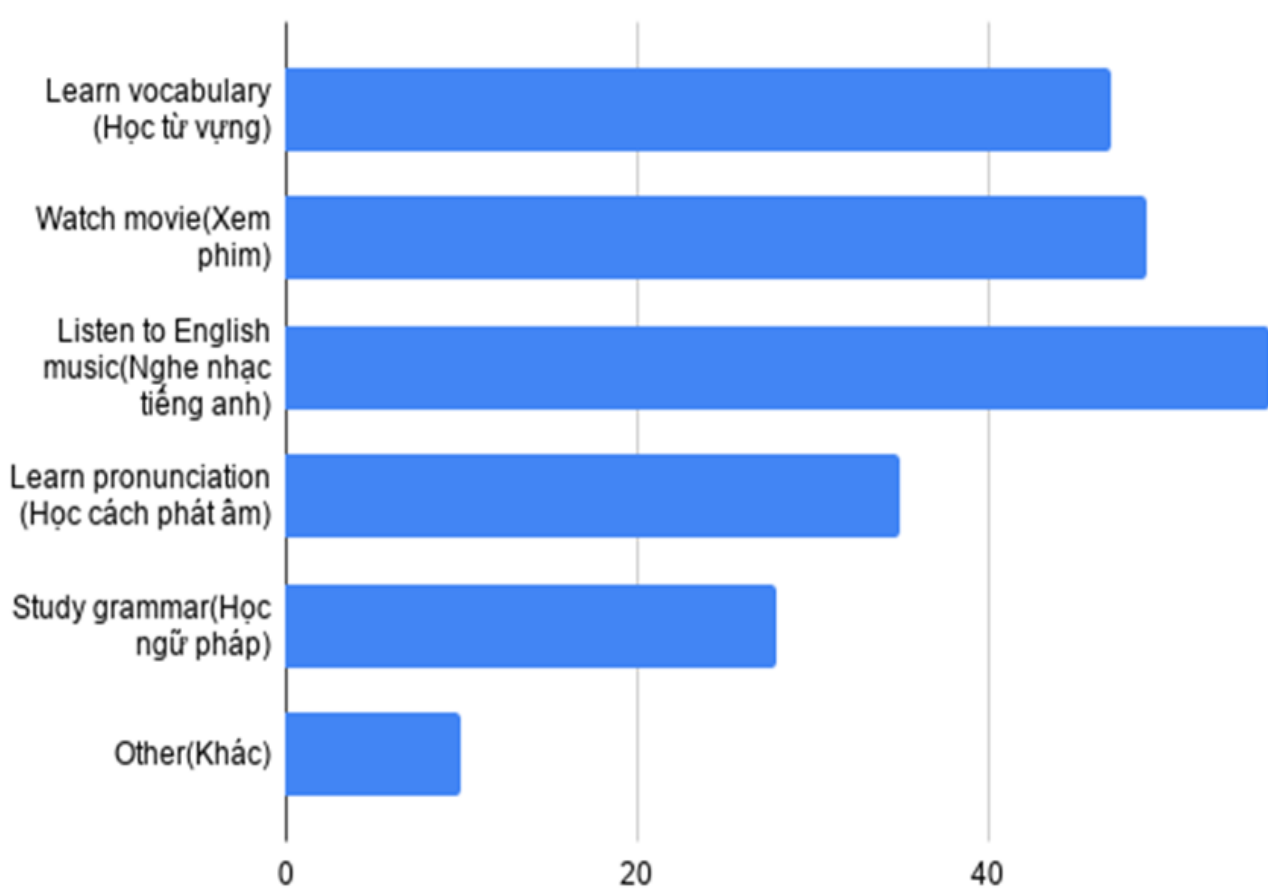

Question 4: What is your method of learning English?

Based on the chart, the method of English learning that students apply the most to improve their speaking skills is listening to English music, accounting for $55 \%$, the second method is watching foreign movies with subtitles, accounting for $50 \%$, and $49 \%$ selfstudy vocabulary every day, learning the pronunciation of native speakers accounts for $37 \%$ and $10 \%$ for other methods.

\section{Conclusions}

Based on the results of research and discussion, it can be concluded that 80 English majors at HUFI are having some problems learning speaking skills. The problems most students face when speaking English are: afraid to communicate, unconfident, nonstandard pronunciations, grammar is not stable, limited vocabulary, few opportunities practice. And most of the students are afraid of making mistakes, saying the wrong thing and lack of motivation in studying. Besides, some important factors such as learning environment and daily language training are also especially important for students in the process of learning English. And it may also be partly due to the lack of many methods by teachers in applying the daily English teaching program and this factor makes students lack motivation to speak foreign languages. Therefore, this problem needs the attention of teachers to be able to overcome as well as to build an effective learning program by using exciting strategies when learning English to create motiva- 
tion. And also facilitate the students to speak English as much as possible. And the results of data collection conducted have shown that there are a number of factors that cause difficulties in learning English that are identified by students in applying the speaking skill program. One of the biggest obstacles identified by students is the fear of communicating with others. This happens because the school environment does not meet the needs of students to use English regularly, and with the failure to apply English as a daily language. This has made students unable to pronounce the word correctly afraid to communicate with others for fear of saying the wrong thing. And the solution to this problem is that teachers and schools should create the best learning conditions and environment for students, should increase English speaking lessons for students more and let students have more time with foreigners so that they can learn the way the teacher speaks from which to gain experience to correct their pronunciation as well as their grammar, and help students practice speaking regularly with a variety of topics and questions, entertain students by creating game activities, solving puzzles, listening to music, watching short films without subtitles to create interest in learning for students without causing boredom and most should use English and also in daily communication. And with the students hoping that people will realize that now English is very important for everyone, everyone should know the importance of English to always try to learn and improve constantly to improve their knowledge, join hands to build and develop the country. Hopefully, these solutions will be effective in overcoming the difficult problems that students face in the process of learning English speaking skills.

\section{Patents}

Funding: Please add: This research received no external funding.

Conflicts of Interest: The authors declare no conflict of interest.

\section{Appendix A}

Survey Question for investigating English prepositions uses

\section{PERSONAL INFORMATION}

1) What's your name?

2) Email address?

3) Gender:
a) Male (Nam)
b) Female (Nữ)

4) Which year are you in?
a) Freshman (Năm nhất)
b) Sophomore (Năm hai)
c) Junior (Năm ba)
d) Senior (Năm cuối)
e) Others (Khác) 
5) Do you like to communicate in english?
a) Yes (Có)
b) No (Không)
c) Maybe (Có thê)

6) In your opinion, what is the most difficult skills in learning foreign language?
a) Speaking skills (Những kỹ năng nói)
b) Reading skills (Kỹ năng đọc hiểu)
c) Listening Skills (Kĩ năng nghe)
d) Writing skills (Kỹ năng viết)

7) How much time do you spend a day learning English?
a) 30 - 1 hour (30 - 1 giờ)
b) 2 - 3 hour (2-3 giờ)
c) 3 - 4 hour (3 - 4 giờ)
d) $4-5$ hour (4 - 5 giờ)
e) Others (Khác)

8) What is your method of learning English?
a) Learn vocabulary (Học từ vựng)
b) Watch movie (Xem phim)
c) Listen to English music (Nghe nhạc tiếng anh)
d) Learn pronunciation (Học cách phát âm)
e) Study grammar (Học ngũ̃ pháp)
f) Others (Khác)

9) What are the difficulties you encounter when speaking English?
a) Afraid to communicate (Ngại giao tiếp)
b) Unconfident (Không tự tin)
c) Non-standard pronunciations (Phát âm không chuẩn)
d) Grammar is not stable (Ngữ pháp không ổn định)
e) Others (Khác) 
10) In your opinion, how to overcome these difficulties?

\section{References}

1. Agustín-Llach, M. P. (2001). Teaching Languages to Young Learners. Open Journal of Modern Linguistics, 40.

2. Brown, H. (1994). Teaching by principles: an interactive approach to language pedagogy. Englewood Cliffs: Prentice Hall Regents.

3. Brown, H. (1994). Teaching by principles: an interactive approach to language pedagogy. Englewood Cliffs: Prentice Hall Regents.

4. Brown, H. D. (2001). Language Assessment Principle and Classroom Practice. New York: Longman.

5. Burns, A. \&. (1997). Focus on speaking. Sydney: National Center for English Language Teaching and Research.

6. D'Arcy-Adrian. (1978). Junior Comprehension 1. England: Longman.

7. Freeman. (2001). Developing Students Speaking Ability. Journal of SMP Negeri 17 Pekan Baru, 56-57.

8. Grognet, A. (1997). Integrating employment skills into adult ESL instruction. Washington, DC: National Center for ESL Literacy Education.

9. Nasional, D. P. (2004). Kebijakan Departemen Pendidikan Nasional Tahun. Jakarta: Badan Pengembangan dan Pembinaan Bahasa.

10. Nghi, T. T. (2021). A Study on Communication Breakdowns between Native and Non-native Speakers in English Speaking Classes. Luu Quy Khuong Journal of English Language Teaching and Applied Linguistics , 2707-756X.

11. Son, P.N. Nghi, T.T. (2019). Designing Songs for Teaching and Learning English: A Literature Review. Journal of Literature, Languages and Linguistics , 2422-8435.

12. Richard. (2008). Teaching Speaking Theories and Methodologies. 19.

13. Risnadedi. (2001). Developing Students Speaking Ability. Journal of SMP Negeri 17 Pekan Baru, 56-58.

14. Rivers, W. (1981). Teaching foreign language skills (2nd ed). Chicago: University of Chicago Press.

15. Tarigan, H. G. (2008). Berbicara: Sebagai Suatu Keterampilan Berbahasa. Angkasa: Bandung.

16. Tran Huu Phuc, N. T. (2019). A Cognitive study of Non-linguistic Factors Affecting the use of Prepositions by Vietnamese Native Speakers. International Journal of Applied Linguistics and English Literature.

17. Wilson, S. (1983). Living English Structure. London: Longman. 